\title{
DESIGN AND IMPLEMENTATION OF E-LEARNING IN POSTGRADUATE TEACHER EDUCATION
}

\author{
I. Vorotnykova \\ Borys Grinchenko Kyiv University (UKRAINE)
}

\begin{abstract}
The article highlights the possibilities of postgraduate pedagogical education for the design and implementation of e-learning. The model of e-learning of teachers in postgraduate education is proposed. E-learning is implemented on the basis of competence oriented, andragogical, systemic and activity-oriented approaches that take into account the teachers' needs and the possibilities of formal and non-formal postgraduate education.
\end{abstract}

Keywords: e-learning, postgraduate education, formal learning, non-formal learning.

\section{INTRODUCTION}

The digitalization of society, the need for the continuous and effective professional development of specialists, the need to obtain new specialties and qualifications, the growing demands for quality, accessibility, and convenience of learning make pedagogical science search for new forms, tools, and methods of teaching. There are contradictions between the speed of change in the IT industry and the state of digitalization of education, the demands of society for the digital competence of teachers and the uncertain legal framework for digitalization of education in Ukraine, teachers' needs for continuing professional development and conservative postgraduate education on the systematic use of ICT, development of SMART-education, increasing number of electronic educational resources and personal unpreparedness of teachers to implement digital technologies. There is a need to design and implement e-learning in postgraduate education. Teachers who participate in e-learning and use IT tools for their professional development are preparing to use them later in their professional activities. Consistent with the radical changes in the educational environment, modern methods and techniques there is the use of different approaches to learning: e-learning, blended learning, mobile learning and ubiquitous learning [1]. Teachers should be prepared to use e-learning [3]. E-learning is changing rapidly [3]. E-learning can be defined as learning through electronic devices using technology as a medium for online interaction and access to information [4].

Nowadays, the term e-learning 2.0 is spreading. This term reflects e-learning trends related to Web 2.0 technologies and cloud services such as blogs, wikis, social networks, etc. The technological trends of e-learning are big data analytics, cloud computing, intelligent sensors (data conversion into digital systems), smart robots and machines and artificial intelligence, augmented (AR), mixed (MR) and virtual reality (VR), smart spaces.

The aim of our research is to develop and substantiate theoretical, methodological foundations of elearning of teachers in postgraduate pedagogical education.

\section{METHODOLOGY}

The methodology is based on the theoretical substantiation of e-learning in postgraduate pedagogical education in the context of digitalization, the design of the e-learning system in formal, non-formal postgraduate teacher education, integration of different models of teacher professional development. The following theoretical methods were used: analysis, systematization, and comparison of scientific provisions to determine theoretical approaches, determination of the conditions for the introduction of e-learning in postgraduate education. We also used empirical research methods. A total of 1440 teachers (2016) and 890 teachers (2019) were interviewed on readiness to implement e-learning in postgraduate education, and the digital competence levels of 300 teachers were analyzed based on self-examination. 


\section{RESULTS}

Adult learning is usually characterized as experienced, problematic, urgent, and self-directed. Unlike children, adults learn experimentally using their own experience, knowledge, and problem-solving skills. They need to know the purpose and opportunities to implement learning outcomes in their professional activities. Adults expect the process of learning to be in a supportive environment that addresses the main aspects of adult learning. In practice, andragogy focuses more on the process (the way we learn) and less on the content (what we learn). The strategies include samples, roleplaying, modeling and self-assessment and are often enhanced by the introduction of different technologies. Instructors act as facilitators, not teachers [5, 35].

\subsection{Design of e-learning in postgraduate education}

The social infrastructure framework systematically frames the design elements from the perspective of four dimensions: cultural beliefs, practices, socio-techno-spatial relations and interaction with the "outside world" [6].

E-learning of teachers should provide lifelong learning, i.e. continuous professional development, improvement of the professional competences of specialists after graduation or postgraduate education throughout their professional activity. We define e-learning design based on ADDIE instructional systems design model.

This model includes the cycle of analysis, design, development, implementation and mandatory evolution at all stages:

- At the stage of analysis, we investigate the needs of teachers in various forms of postgraduate education (formal, non-formal, informal), the readiness of teachers and teacher educators for elearning, their digital competence, determine the aims and objectives of e-learning courses, IT infrastructure of postgraduate education.

- At the stage of design, we design e-learning courses using Bloom's taxonomy and the KAR-P-E taxonomy - a technological education schema that encompasses adult education, corporate training, and professional development, according to a specific aim and objectives. The educational design of educational aims is based on knowledge, application, research, practice, and evaluation (KAR-P-E), which provides for the acquisition of new competencies by teachers and their implementation in their professional activity "Fig.1"

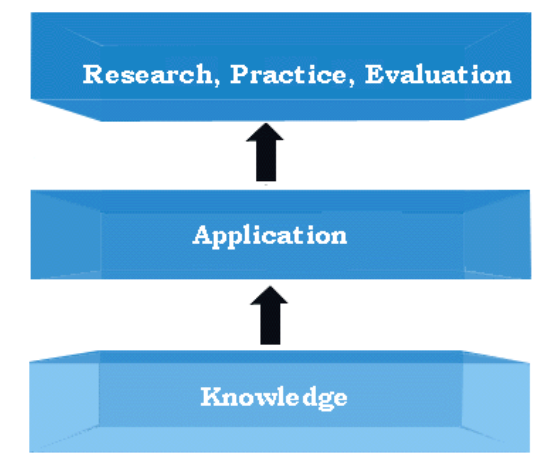

Figure 1. KAR-P-E taxonomy [7, p.37].

Teacher training strategies are included in the SQD (Synthesis of Qualitative Data) model, which components are: educators who are role models and who understand the role of technology in education, teaching how to use technology through design, collaborating with colleagues, scaffolding authentic technology experiences, providing constant feedback [8].

Constructivism learning theory, especially social constructivism in education [9], is a form and design of e-learning. This means that successful learning depends on individual activities and collaboration.

Teachers with a high level of professionalism use the concepts of connectivism to set their own learning goals and networks in collaboration with their colleagues.

The design should also take into account the capabilities of the Web 2.0 IT tools, artificial intelligence and special software (remote platforms, virtual learning environments, online tutorials, etc.). 
- e-learning development is ensured by continuous improvement of e-learning, IT infrastructure of postgraduate teacher education, preparation of teacher educators for e-tutoring, e-coaching based on the feedback analysis of participants in the educational process.

- implementation of e-learning in postgraduate education is ensured on the basis of formal and non-formal e-learning development, creation of adaptive distance e-courses, the introduction of e-learning elements (testing, monitoring, interactive lectures using gadgets, etc.) at seminars, in-service training, offline, face-to-face training with a teacher, a facilitator.

The cycle ends and begins again with an analysis of the factors that need attention to modernize elearning to meet the needs of teachers and the rapidly developing IT tools.

\subsection{Implementation of e-learning in postgraduate education}

The conditions for the introduction of e-learning in postgraduate education have been defined as follows: normative (introduction of e-learning, availability of educational policy of the educational institution), personnel (readiness of teachers and teacher educators for e-learning); educational and methodological (electronic educational resources, programs, teaching methods, information, and educational environment); technical (IT infrastructure of the institutions, availability of teachers' gadgets).

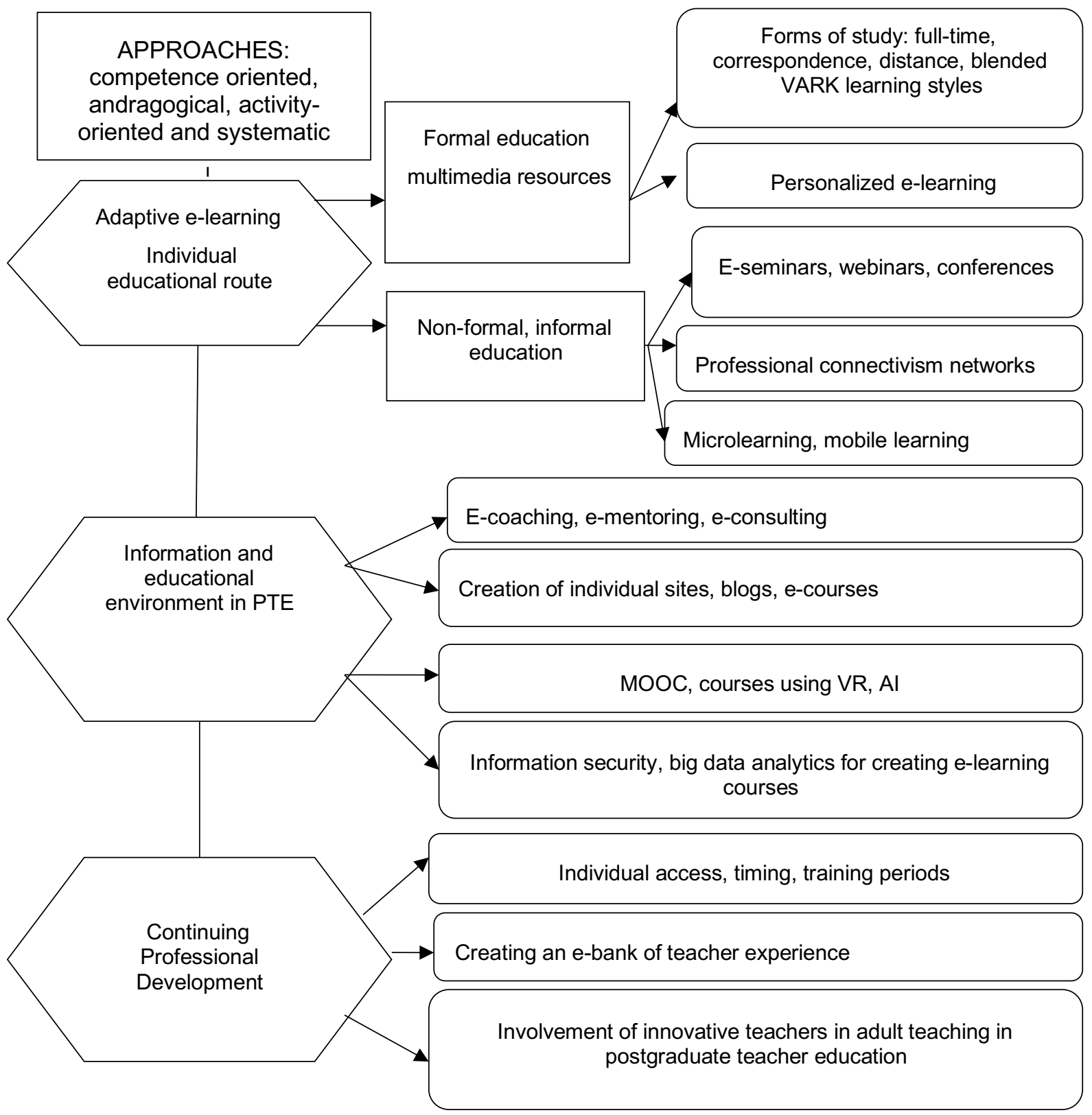

Figure 2. A model for introducing e-learning in postgraduate education. 
The postgraduate pedagogical education e-learning model is built on competence oriented, andragogical, activity-oriented and systematic approaches ("Fig.2"). According to the teachers' needs in different models of postgraduate education, different elements of e-learning can be implemented or integrated. For example,

- Long-term models of advanced training can use distance courses and MOOCs from reputed universities (Edex, Coursera, Udemy, MOODLE, etc.), and short-term ones can prefer microlearning (Gnowbe, OttoLearn Microlearning, etc.).

- Person-centered, competence oriented models of advanced training should take into account the teachers' needs in full-time, blended learning and provide them with interactive electronic multimedia resources and e-tutoring, e-coaching, e-consulting (Bigbluebutoon, ZOOM, Skype, Hangouts, Padlet, Blogger, etc.)

- Mentoring models in which knowledge is cascaded from experts, who train new experts have to provide teachers with the opportunity to create their e-resources, including networks (MS Office 365, WordPress, Moodle, Google class, Edmodo, etc.).

- Model "A Learning Organization" has to integrate methods of projects, cases, pieces of training, exchange of experience, webinars, self-education using ICT.

\subsubsection{Readiness of teachers and andragogues to e-learning}

Several studies have shown that successful pedagogical use of technology depends on the attitude of teachers, acceptance of e-learning, readiness for it. Subjective norm and computer self-efficacy are two important factors for this. However, perceived usefulness and ease of use are also significant in predicting educators' intention to use e-learning [10].

A survey of 1440 teachers in Kyiv in 2016 showed that $45.6 \%$ of them are ready to study digital technologies and improve their digital competence, $39 \%$ are ready to get postgraduate education in the field of e-learning, but they said that there was a need for blended learning, electronic modules should take into account the teaching styles and meet teachers' needs. In a survey of 890 teachers in 2018 , only $23 \%$ identified their willingness to use e-learning and mastering IT tools for professional activity.

For the implementation of e-learning in postgraduate education, teachers' readiness for e-learning has been analyzed, criteria for the design of e-learning courses have been defined and tools for digital self-evaluation of teachers' competence based on materials (DigCompEdu) have been adapted [11].

Most teachers (52\%) found that they had an insufficient level of digital competence in awareness and researching, which meant that they were not confident in using ICT for professional development and professional activity. The analysis showed the need for teacher training. 17 modules for the development of teachers' digital competence in the fields of information and data literacy, communication and collaboration, digital content creation, safety, problem solving have been developed. The SWOT analysis of teachers' needs showed the possibilities of using e-learning elements: e-coaching, e-tutoring in the conditions of development of e-learning in postgraduate education.

The survey found that $17 \%$ of teachers stated that they were using digital technology at the innovation level. These teachers need the development of adaptive e-learning, the creation of professional development networks to engage them in the exchange of experience through the use of theories of social constructivism and connectivism. To get the expected results of teachers' professional development, post-graduate education facilitators have to implement an ICT-based curriculum, develop multimedia learning models and implement e-learning. For example, Borys Grinchenko Kyiv University has started a program of training e-learning managers who receive a pedagogical education and have all the necessary competencies to implement e-learning. 


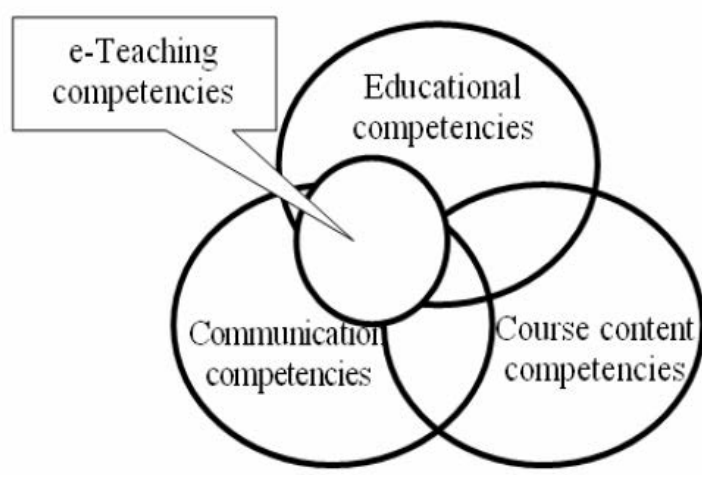

Figure 3. Structure of teachers' competencies

\section{CONCLUSIONS}

We propose that e-learning in postgraduate education should be based on the ADDIE instructional systems design model. For the design and implementation of e-learning in postgraduate education, we have to determine the readiness of teachers and teacher educators for such activities, to analyse the availability of IT infrastructure for formal and non-formal adult education, including electronic educational resources (professional communities, networks, e-courses, etc.). E-learning can be implemented on the basis of competence oriented, andragogical, systemic and activity-oriented approaches that take into account the teachers' needs for the possibilities of formal and non-formal postgraduate education. The e-learning design is based on Bloom's taxonomy and the KAR-P-E taxonomy - a technology education schema that encompasses adult education, corporate training, and professional development. To implement the model, it is necessary to define the conditions for the introduction of e-learning in postgraduate education: normative (introduction of e-learning, availability of educational policy of the educational institution), personnel (readiness of teachers and teacher educators for e-learning); educational and methodological (electronic educational resources, programs, teaching methods, information, and educational environment); technical (IT infrastructure of the institutions, availability of teachers' gadgets).

Successful e-learning also requires a broad national infrastructure to be created and used for the needs of a knowledge-based economy [13, p.31].

E-learning should ensure the personalized continuous professional development of a teacher and be adaptive. Different models of postgraduate education can use and integrate a variety of IT tools and environments [14].

Further studies should investigate the identification of psychological and pedagogical conditions and technical and technological features of e-learning and testing of the developed models in terms of the educational process; determination of quantitative and qualitative characteristics of e-learning effectiveness, dynamics of professional development of teachers.

\section{REFERENCES}

[1] H. Keser and A. Semerci, "Technology trends, Education 4.0 and beyond". Contemporary Educational Researches Journal. vol.9(3), pp.39-39, 2019. DOI: 10.18844/cerj.v9i3.4269

[2] D.R. GARRISON, "E-learning in the 21st century: A framework for research and practice". Routledge, 2011.

[3] A. H. K. Yuen, and W. W. K. Ma, "Exploring teacher acceptance of e-learning technology,", AsiaPacific Journal of Teacher Education, Article vol. 36, no. 3, pp. 229-243, 2008, doi: 10.1080/13598660802232779.

[4] W.H. Wu, , Y. C .Jim Wu, C. Y. Chen,, H.Y. Kao, C.H Lin, and S.H Huang,. "Review of trends from mobile learning studies: A metaanalysis", Computers \& Education, vol.59, pp.817-827, 2012.

[5] Terry T. KIDD ,"Online education and adult learning: new frontiers for teaching practices: new frontiers for teaching practices" (Editors eds.). IGI Global, 2009. 
[6] K. Bielaczyc, "Designing social infrastructure: Critical issues in creating learning environments with technology," (in English), Journal of the Learning Sciences, Article; Proceedings Paper vol. 15, no. 3, pp. 301-329, 2006, doi: 10.1207/s15327809jls1503_1.

[7] L. A. TOMEI, "The New Taxonomy for the Technology Domain: A Classification of Educational Objectives for the Technology Domain". INFORMATION MANAGEMENT,-HARRISBURG PA-, 18.3/4: 6, 2005.

[8] Jo Tondeur, R. Scherer E. Baran, F.Siddiq, T. Valtonen, and E. Sointu, Teacher educators as gatekeepers: Preparing the next generation of teachers for technology integration in education. British Journal of Educational Technology. Vol.50, pp. 1189-1209,2019. doi: 10.1111/bjet.12748.

[9] E.Carnell,.."Conceptions of effective teaching in higher education", Teaching in Higher Education, vol.12(1), pp.25-40, 2007.

[10] A. H. K. Yuen, and W. W. K. Ma, "Exploring teacher acceptance of e-learning technology,", AsiaPacific Journal of Teacher Education, Article vol. 36, no. 3, pp. 229-243, 2008, doi: $10.1080 / 13598660802232779$.

[11] C. Redecker "European framework for the digital competence of educators: DigCompEdu (No. JRC107466)". Joint Research Centre (Seville site), 2017. [E-Reader Version]. Retrieved from https://ec.europa.eu/jrc/en/publication/eur-scientific-and-technical-research-reports/europeanframework-digital-competence-educators-digcompedu2017.

[12] D. Bjekic, K. Radojka, and M.Danijela. "Teacher education from e-learner to e-teacher: Master curriculum". Turkish Online Journal of Educational Technology-TOJET, vol.9.1, pp. 202-212,2010.

[13] T. Bates, and UNESCO-IIEP, National Strategies for E-learning in Post-Secondary Education and Training, 2001. [E-Reader Version]. Retrieved from:http://lst-iiep.iiep-unesco.org/cgibin/wwwi32.exe/[in=epidoc1.in]/?t2000=014671/(100).

[14] I.P. Vorotnykova and N. V. Zaierkova, "E-learning of teachers' assistants in postgraduate pedagogical education" (in Ukrainian), Information Technologies and Learning Tools, vol. 66, no. 4, pp. 231-244, 2018, doi: 10.33407/ittt.v66i4.2126. 